\title{
Cultural Expertise in Sweden: A History of Its Use
}

\author{
Annika Rabo
}

Department of Social Anthropology, Stockholm University, 10691 Stockholm, Sweden; annika.rabo@socant.su.se Received: 25 April 2019; Accepted: 11 September 2019; Published: 17 September 2019

\begin{abstract}
This paper is a case study of the use of cultural experts, broadly defined as including mediators and academicians with a variety of backgrounds, in Sweden. It draws on data collected through qualitative interviews with cultural experts, by following court cases through legal documents, mass media and other printed material, and by my own experience as a cultural expert. The paper provides a context to the potential application of the concept of cultural expertise regarding the appointment of such experts by lawyers, prosecutors and courts. It analyzes cases concerning the Sami, the Roma and recent immigrants from Africa and Asia. The Sami cases revolve around conflicts with the Swedish state over rights and ownership. The Roma cases revolve around questions of ethnic discrimination. Cases of immigrants from outside Europe consist of individual criminal cases and asylum. I argue that Swedish ideas-and ideals—of sameness and equality have had an impact on the legal cases that I discuss in this paper. While the legal issues in each of these cases differ, the paper argues that they demonstrate a similarity in how Swedish-majority society manages and even creates cultural differences. I conclude by showing the ways culture, rights, and obligations are understood in courts reflect mainstream trends of Swedish society and suggest the need for cultural expertise in the form of interdisciplinary collaboration.
\end{abstract}

Keywords: experts; cultural experts; court cases; Sweden; Sami; Roma; immigrants

\section{Introduction}

"In just a short while the ethnic composition of the Swedish population has changed in a noticeable way without greater conflicts between different groups. Lately, however an increased social segregation with ethnic components, has been observed" (SOU 1996, p. 55). ${ }^{1}$

These are the opening sentences of the summary of a 500-page official government report Sweden, entitled The Future and Multiculturalism, ${ }^{2}$ by the parliamentary Immigrant Committee which worked between April 1995 and April 1996. It consisted of 12 members of parliament and was chaired by the governor of a northern province. Experts, or sakkunniga, ${ }^{3}$ from various ministries were used, and a number of people with expertise in migration and integration issues were consulted. The report underlines that Sweden has become a multicultural society with around 300,000 born in another Nordic country, 300,000 born in other European countries, and 320,000 born in the rest of the world. In addition, 700,000 persons are born in Sweden but with one or both parents born outside the country. ${ }^{4}$

The opening paragraphs in the report are significant, not by stressing that Sweden has changed though the presence of many immigrants, but that Sweden's multiculturalism is caused by this new

\footnotetext{
All translations from Swedish to English are my own. Original texts in English will be indicated.

The Swedish word is actually mångfald — more akin to diversity-but it is commonly translated as multiculturalism.

Sakkunnig (i.e., "those who know their thing") has a slightly different semantic field compared to expert. It was interesting that the Committee had used both sakkunniga and experter in their work. For sake of simplicity I will use the term expert.

4 Since the mid-1990 these numbers have changed. In late 2017, according to official statistics, almost $19 \%$ of the population was born outside Sweden.
} 
ethnic composition of the country. Researchers point out that Sweden has had a long history of immigration, and that the country has always been linguistically, culturally and ethnically diverse (e.g., Svanberg and Tydén 2005). Yet, the idea of a homogenous Sweden still persists. There is a tension in how the state and public agencies have viewed—and still view-sameness and difference among the population. Diversity and multiculturalism are lauded but are simultaneously perceived as divisive and even dangerous. It was only in 2000, for example, that Sweden ratified the Council of Europe's Convention for Protection of National Minorities, and the European Convention on Minority Languages. Jews, Roma, Tornedalers, Sweden-Finns and Sami were then recognized as national minorities. The Sami were also given the status as indigenous people. Jiddish, Romani Chib, Finnish, Meänkieli, and the different Sami languages and dialects were simultaneously recognized as national minority languages ${ }^{5}$. These national minorities have very different historical relations to Sweden and to the Swedish state, and very different relations to experts who have either helped, or blocked, their demands for recognition. In turn, these relations are different from the ones formed by the more recent non-Nordic immigrants, who today vastly outnumber the national minorities. ${ }^{6}$

In this article I will look at the history and use of cultural experts-persons who "locate and describe relevant facts in light of the particular background of the claimants, litigant or the accused person(s), and in some cases the victim(s)" (Holden 2011, p. 2; Holden 2019b, pp. 199-200) in Swedish cases involving national minorities and newly arrived immigrants. The court is an excellent arena to analyze how cultural differences and similarities are implicitly understood, promoted or managed. The material is based on face-to-face and e-mail interviews with academic colleagues in anthropology, law, political science, social work, theology and religious studies. I have also followed the paper trail of some legal cases. However, given the novelty of the theoretical underpinning of cultural expertise, instead of engaging in an in-depth but necessarily selective analysis, I have decided to provide a general overview of the use of cultural expertise in Sweden in a narrative format that sometimes interweaves with verbatim extracts of my interviews.

\section{Experts in and out of Court}

In Swedish courts, the so-called free sifting/consideration of evidence (fri bevisprövning) is used. Unlike in Anglo-Saxon legal tradition, there are, in principle, no limitations concerning the sources that can be used by the parties in a trial. The court decides the value of each piece of evidence and assesses the sum of information given. The principle of free sifting of evidence, according to the legal scholars that I interviewed, opens up for the possibility of using all kinds of nonlegal experts in court. However, they noted that the conceptualization of "cultural experts" is new to them. ${ }^{7}$ Claes Lernestedt, who is a professor of penal law, said that in cases of criminal law involving physical injury, or psychological illness or deficiencies, experts are routinely acting as witnesses, or sending in statements, but in criminal cases involving sex, for example, the court sees itself fit to have expertise. However, at least three types of Swedish litigation include some kind of cultural expertise: those involving the Sami, Roma, and immigrants.

Historically, academicians have played a very important role in policy making and in public debates in Sweden. In the 19th century particularly, medical doctors came to supplant the expertise of the Swedish clergy as arbiters of human behavior in the name of progress and modernity, both inside and outside the court. Policies to modernize and develop Sweden and its inhabitants were prevalent from the 1930s to the 1960s, and experts of different kinds were used to push for, and legitimize, social reforms. In this social engineering endeavor, citizens deemed underdeveloped were powerless to protest. In the past, different kinds of experts have been very important in supporting

5 For government policy, see (Government Offices of Sweden 2007)

6 Statistics and registers based on ethnicity or religion is not allowed in Sweden. In official statistics, only country of birth is noted (SCB 2018).

7 Cultural expert (kulturexpert) is not an officially used concept in Sweden. 
the claims of the state, and public authorities, against the interests of the Sami and the Roma. In the contemporary period, cultural experts acting as expert witnesses in Swedish cases of litigation come from social activism, public relations, academia, or other institutional appointments on behalf of either side in conflict.

In the following section, I give a brief overview of the historical trajectory of the Sami and the Roma in Sweden, as well as the history of recent immigration to Sweden. This is followed by cases of litigations in which Sami and Roma people have been involved. Then the emergence of experts in the culture of non-European immigrants is discussed, followed by expert involvement in some cases of violent crimes which have received public attention. Subsequently, the relations between law, experts and culture are discussed, and I conclude by analyzing how experts are part of both rejecting and affirming cultural differences in contemporary Sweden.

\section{The Sami, the Roma, and the New Immigrants}

The Sami had been present in the northern part of Fenno-Scandia long before the establishment of states in the region. In the 14th century, the boundaries of a Swedish state expanded northwards, and the Sami were associated with long-distance trade in meat, fish, and furs-goods which were coveted in the south. The relations between the crown and the Sami were for centuries generally peaceful, and their rights over land were recognized. From the middle of the 17th century until the beginning of the 20th century, Sami villages in the far north of Sweden were divided into so-called taxed-land. Initially, such land was treated as inalienable property on which the villagers paid tax. Towards the end of the 17th century, regional representatives of the state started to claim that the land belonged to the crown. During the 19th century, when the natural resources in the north-forests, water, and iron ore-became essential for Swedish industrial development, the rights of the Sami diminished (see Lundmark 2006). In the late 19th century, a law was passed which regulated the rights of Sami reindeer herders. As a consequence, this particular activity became the basis of how, and for what purposes, the state recognized the Sami. The Swedish authorities have made a sharp distinction-in fact, created a legal difference-between reindeer-herding Sami and Sami with no reindeers. This legal difference has also been the cause of intra-Sami conflicts. ${ }^{8}$ In the following section, the Sami cases of litigation concern the Sami organized in reindeer villages.

The first Roma probably reached Sweden in the 16th century (Nafstad 2016). Other groups of Roma came from France and Russia in the end of the 19th century. A large subgroup arrived from Finland in the 1950s, and in the 1960s, Roma from parts of Europe arrived. After the turn of the 21st century, finally, Roma from the Balkans, Bulgaria, and Rumania also arrived. In 2014, the government issued a white paper, documenting how, in the first half of the 21st century, the Roma had been denied the right to settle, how Roma children had been taken from their parents, and how Roma women had been sterilized, all underlining that they were not seen as part of society but as inferior outsiders (Ds 2014, p. 8). This paper focuses on cases of litigation where the Roma accuse individuals or the state of ethnic discrimination.

After World War II, Sweden became a country of immigration rather than of emigration. ${ }^{9}$ The Swedish industries were in great need of workers and most came from neighboring countries, as noted above, and particularly from Finland. In the late 1950s and the 1960s, many also came from Italy, Greece, the former Yugoslavia, and Turkey. In the late 1970s, labor migration more or less came to an end, and instead immigrants have been people seeking refuge in the country and persons seeking family reunification. For decades, persons born in Finland constituted the most numerous group born outside Sweden. Now persons born in Syria have taken that place, followed by those born in Finland,

8 For analysis of this complicated history, see Mörkenstam (2002).

9 About $25 \%$ of the population left Sweden, mainly for the USA, from the early 19th to the early 20th century. 
Iraq, and Iran. ${ }^{10}$ This means that a great many of the immigrants who have arrived in the last few decades come from countries with a Muslim majority population. In the eyes of certain segments of the population, the emblematic immigrant is a Muslim and associated with a particular culture which may lead to gender-based crimes reflecting patriarchal values. The discussion in this paper touches on the role of experts in asylum cases but mainly focuses on cases where immigrants have been accused of violent crimes.

\section{Sami Court Cases}

The Sami, as much as the Roma, have for a long time been subjected to, and oppressed by, religious, medical, educational, and legal experts at the service of the Swedish state and official policies. ${ }^{11}$ But they have also organized themselves and found their own experts, from within or outside their own associations. In the Sami case, the legal battles have focused on rights to land and control over hunting and fishing. The most famous case was the 'Taxed mountain case' (Skattefjällsmålet), in which Sami villages sued the Swedish state to gain better and more secure access to land and water. The case started in 1966 and continued until 1981, passing through all instances. No other legal case in Sweden has continued for so long and no other verdict, which covered 100 pages, has been so extensive. Experts on law and history were used by both sides. The state used its experts to claim the historical right of the crown in the north of Sweden. The Sami used historians with expertise on the development of their settlements in the north. In the end, the Sami villages lost against the Swedish state and had to pay for the lengthy process. But the verdict also stated that nomadic people can acquire ownership rights to land and water by having used it since 'time immemorial' (urminnes hävd) or by occupying 'empty land'. ${ }^{12}$

In 1990, private landowners and a forestry company in the region close to that of the Taxed mountain case province sued five Sami villages claiming that they had no customary rights (sedvanerätt) to graze their herds in nonmountain areas. This time, it was not the state, but private interests against the Sami. Six years later, a district court pronounced that the Sami had lost the case. The Sami took it to a court of appeal but lost in 2002, and in 2004, the supreme court decided not to take on the case. ${ }^{13}$ This loss made land-owners further north take other Sami villages to court. But this time, another district court judged that the Sami had the right to herd reindeers on the land. The court of appeal gave the same verdict, as did the supreme court in 2011. This case was the first won by the Sami after 40 years of legal battles. There have been other legal cases which have resulted in a distinction between rights based on time immemorial, and customary rights. The first concerns the right based on usage for such a long time, in that no one can remember when it started. The second is based on the use having been accepted for a long time, thus making it normal. Legal perception has shifted so that customary use is enough for the Sami to have the right to graze private lands. This has been an advantage for the Sami who are seldom able to produce documents concerning use since time immemorial.

Another bone of contention has been the right to hunt and fish in the mountain areas in the north of Sweden, which the state regards as owned by the crown. In 1992, the Swedish parliament decided to liberalize access to hunting and fishing in these areas. The Sami protested in various ways. In 2009, the National Sami Organization and the Sami village of Girjas sued the state in a district court in the far north, claiming that their rights had been undermined through the new law. The case took a long time to be heard, and when it did in 2015, the Sami and more than 50 researchers from a great many disciplines in the humanities and social sciences were outraged by the vocabulary used by the experts and witnesses of the state. The researchers made a petition claiming that the use of research about

10 Finns have lost 'the lead' because they are an ageing group with limited 'replenishment' from Finland.

11 For Ph.D. dissertations on the problematic and often offensive relation between the state and the Roma, see e.g., Runcis (1998), Olgaç Rodell (2006), Nafstad (2016), the state and the Sami, e.g., Beach (1981), Mörkenstam (1999).

12 For texts in English concerning this case, see Jahreskog (1982).

13 The cases were very expensive for the villages, and they ended up with a debt of about 1.7 million euros. 
the Sami on the part of the Swedish state was flawed. "Years of Swedish and international research is rejected and the language used is a remnant from the era of race biology" (Dagens Nyheter 2015). In February 201,6 the district court decided in favor of the Sami village. The Swedish state appealed. In 2018 the court of appeal, however, decided that while Girjas village holds rights to fishing and hunting, these rights are shared with the state. The case reached the supreme court, and the session is scheduled to take place between 2 September and 10 October 2019.

In the Taxed mountain case, both the Swedish state and the Sami, as noted above, used experts on history and the legal history of the north. The Sami have also increasingly developed their own expertise and been able to find lawyers who can represent them. All these kinds of experts fall into the integrated definition of cultural expertise (Holden 2019a).

\section{Roma Court Cases}

In November 2013, the largest Swedish daily, Dagens Nyheter, published news that the police in the southern city of Malmö had a register containing the names of 4700 Roma, or people closely linked to Roma individuals. One thousand were children and 200 were deceased. The police claimed that the register fulfilled the purpose of criminal investigations, but the public authority for security and integrity quickly decided that the register was against the law. However, when asked, the judiciary did not identify the register as an ethnic directory. The Chancellor of Justice instead decided that the personal integrity of all individuals on the register had been violated and awarded everyone whose name was on it 5000 Swedish kronor. ${ }^{14}$ Many Roma were dismayed that the state did not recognize that they had been registered because of their ethnic background, and some wanted to appeal. In March 2015, 11 of those registered - three of them children—sued the state, with the help of the Civil Rights Defenders. ${ }^{15}$ The case was heard in the district court of Stockholm, and a year and a half later, the Roma won the case against the state. The court decided that they had been registered only because of their ethnic background, and each litigant was awarded 30,000 Swedish kronor. The state brought the case to the court of appeal but lost and instead settled the verdict of the district court. The state could not show that the register was unrelated to ethnic discrimination. A month later, at the end of May 2017, the Chancellor of Justice, in a surprising move, decided that all persons in the police register would be entitled to the same amount as that awarded to the 11 persons in the court case. They would have to apply individually for the compensation, and if all did, this would amount to the largest damages paid by the Swedish state, caused by a single event. The damages-164 million kronor-would be paid by the police authority.

This court case is unusual, not only because it was won by the Roma, but also because it involved so many people. The most reported cases of discrimination in Sweden concern individual Roma or Roma families who are prevented from entering shops, hotels, restaurants or denied renting an apartment. In the summer of 1980, for example, the owner of a camping site in the middle of Sweden put up a sign saying that Roma were not welcome. A family was denied entry but filed a complaint, and the district attorney sued the owners. The district court judged that this was a case of agitation against an ethnic group (hets mot folkgrupp) and that the owner must pay a fine. In the court of appeal, the owner also received a conditional sentence. In the supreme court, finally, the owner was judged to have agitated against an ethnic group, but the conditional sentence was removed.

In another example, from 1996, the district attorney in a southern town prosecuted the owners of a retail outlet. They denied access to Roma women because they claimed that their voluminous skirts were used to hide stolen goods. One Roma woman went to the outlet together with a journalist. She was not allowed to enter, a fracas erupted, the case got media attention, and the woman filed a

14 Ten kronor is about one euro.

15 Civil Rights Defenders (previously known as the Swedish Helsinki Committee for Human Rights) is an independent expert organization founded in Stockholm in 1982 with the aim of defending human rights, in particular people's civil and political rights. 
complaint. The owners claimed that they denied access to all with large skirts. The district court could not find that she had been discriminated against because of her ethnic background, but the attorney continued to the court of appeal. This court concluded in favor of the Roma woman, but the owners of the outlet took the case to the Supreme Court. In September 1999, the verdict of the court of appeal was decided, and the owners had to pay a fine to the state and 5000 kronor in damages to the woman.

In the cases above, experts were not instructed systematically. Yet the Roma have become organized in new ways and have spokespersons of different kinds. In the case of the Roma women and their skirts, Karl-Olov Arnstberg, an ethnologist with research experience on the Roma, was appointed to testify on the clothing patterns of different groups in Sweden. He underlined that among the Roma with a Finnish background, the large and heavy skirt was, more or less, mandatory for adult women. This kind of skirt, in the eyes of the public at large, typically signals that the bearer is Roma. The outlet owners could, hence, not claim that they were simply preventing women in general that wear large skirts. In the large register case, there was an expert witness in the district court who testified on the long history of Roma ethnic registers-the Nazis being the most notorious for keeping such records. Such a history has affected the well-being of the Roma in a very negative way. Fred Taikon, a Roma activist and editor of the journal É Romani Glinda, was among the ones who sued the Swedish state. Being on the huge police register has negatively affected many of the Roma, he told me. "It is still with us. My grandchild cannot speak about it. He gets psychological problems if he has to contact the police for any reason due also to previous instances of discrimination ... For the register trial we had no access to psychological counselling, which we really needed. And there are other cases ... The social services have forcibly taken so many of our children and this has been traumatic for both parents and children ..."

The Roma have been particularly vulnerable to ill treatment and outright discrimination, by a segment of the authorities who were backed by their experts. The Equality Ombudsman, DO, ${ }^{16}$ gets frequent reports from the Roma about discrimination. "Last year we had about fifty ... which is about average for a long time. But this is probably only the tip of an iceberg", according to Lars Lindgren who works as an investigator at DO (Dagens Nyheter 2014). Ingrid Schiöler, who has fought for the rights of the Roma for the past 40 years, told me that she has worked on cases involving young Roma and the social services, produced expert reports supporting Roma asylum seekers, and represented Roma in litigations involving the social services: "I have tried to underline that we have a legal framework for the rights of minorities and that the Roma are, in fact a national minority. The typical response from the official representatives of the majority of society has been to claim that 'here we treat all people in the same manner and we make no exceptions.'" In addition to showing an uneven but de facto well-known use of cultural experts and cultural expertise, Roma litigation points at a major component of justice's perception in Sweden: the primacy of formal equality before the law; or in other words, the idea that taking into consideration the context of facts and litigants may amount to an undue impact on the very notion of justice.

\section{Experts on 'New Immigrants'}

Who are the experts used in court cases and litigation involving non-European immigrants and refugees? To find out more, I corresponded with a number of scholars specialized in research on Islam and Muslims. One was Jan Hjärpe, the best-known scholar of Islam in Sweden, and the first to be appointed as a professor of contemporary Islam in Sweden in 1983. Jan Hjärpe has published extensively also for a general audience and has given frequent popular lectures, as well as making media appearances. He wrote that in the almost 50 years in which he has been active in academia,

16 The Equality Ombudsman (DO) is a government agency that works on behalf of the Swedish parliament and government to promote equal rights and opportunities and to combat discrimination. In Swedish, the agency is actually called 'the discrimination ombudsman.' 
he has only been appointed as an expert in three trials. However, like many other scholars of Islam and Muslims, he has frequently been asked by lawyers to write statements to give a broad context of the situation of their clients. "In general it has been cases of deportation where I have been asked to assess the risk for persons to be deported. The questions have been put by the legal representatives of the person to be deported. In general, they ask questions about legal issues related to Islamic jurisprudence and to legal practice in different areas but also questions about jurisdiction; the state or the family. I have also written statements on questions of apostasy, family law, and custody of children. The initiative to find me and ask me for my opinion has typically come from a (private) person who had become engaged in the case. All in all I must have written between 50 and 100 statements throughout the years, mostly in the 1980s, more seldom nowadays. ${ }^{17}$ These statements were written and presented in court without me being present." This kind of cultural expertise is similar to the practice of expert report writing described by sociolegal scholarship in the United Kingdom (Good 2006; Holden 2011), where the expert's duty is to the court. However, more often than not, it has been rather perceived in terms of cultural defense in which the expert takes sides and uses cultural expertise for the defense (Renteln 2004).

He continued to tell me that he had been called as an expert witness a few times where the case was later not brought to trial because the parties involved had solved the issue themselves, with the help of the extended families. In fact, the plaint from which the case originated was apparently a strategy to exert pressure on one of the parties in the internal negotiations. One of his appointments as an expert in court concerned a trial involving the adoption of Syrians. The case was very muddled, he recounted, and ultimately involved the question of the religious leadership among a branch of the Alawis in Syria. Hjärpe was convinced that the case must have been a very strange experience for the judge and the lay judges. Another case, details about which he hardly remembered anymore, concerned violence between two families with immigrant backgrounds. And then, there was a notorious case in 1989 concerning hate speech against Jews on a radio channel (Radio Islam) which an immigrant from North Africa had started. Hjärpe, and another religious studies scholar, were called in as experts by the defense. The case was widely covered in mass media before, during and after the trial, and the two scholars were generally—and wrongly—-portrayed as defending the views of the accused. The accused was sentenced to six months in prison. ${ }^{18}$

Other scholars of Islam and Muslims have told me that although they have written many statements for various court cases, they have seldom been called as experts to trials. Professor Jonas Otterbeck said he had been called twice; one case of threat and the other of religious discrimination. "In the latter case I made a written statement, as well as answered questions in court." Mohammad Fazlhashemi, the first Swedish professor in Islamic theology, and a scholar with particular expertise on Shi'a theology and jurisprudence, has been contacted by a few lawyers working for women born in Afghanistan. They were seeking divorce in Sweden through the Shi'a talaq ghi'abi, which can be applied when the husband has disappeared or refuses to be contacted. "These are the only family law cases I have been involved in. But I have written on the opinions in Islamic jurisprudence-both Sunni and Shi'a views-on desecration of corpses. It was in a case on war crimes in the south of Sweden, which passed through both the district court and the court of appeal. I was asked by the prosecutor, who wanted to know if there is support for desecration of corpses in Islamic jurisprudence. The accused had apparently tried to hide behind religion to explain his hideous act. On another occasion I have written a statement on various interpretations concerning the shaking of hands between women and men in Islamic jurisprudence. It was DO (the Ombudsman for Equality) who asked me. Later on I was also called to answer questions during the session at the Labor Court." In Swedish mass media, there

17 In large part thanks to Jan Hjärpe, the study of contemporary Islam and Muslims has expanded considerably in Sweden, and hence, the pool of potential experts has increased since the 1990s.

18 In the logic of much contemporary racism, the convicted man has since become strongly aligned with extreme right-wing Nordic supremacist groups. 
have been much debated cases of Muslim men refusing to shake hands with women. In a few cases, their employer tried to fire them. The Ombudsman for Equality was called in and the scholar was instructed as the expert at the Labor Court. ${ }^{19}$ In 2019, Mohammad Fazlhashemi was appointed by the prosecutor as an expert in a case where a man had posed with dead bodies and posted pictures on social media. This person had taken part in battles against the Islamic State. He was sentenced for war crimes by the court and sent to prison.

This very rapid survey of cultural expertise for litigation and legal proceedings involving so-called new immigrants confirms my previous observation regarding, on the one hand, the difficulty to conceptualize cultural expertise and identify cultural experts in Sweden, and on the other, the increasing but uneven occurrence of the appointment of experts that according to Holden's definition would be qualified as cultural experts.

\section{Violent Crimes}

Reading or hearing about the details in the cases of assault, torture or killing of young children is, of course, very distressing. Jan Hjärpe later wrote: "I remember that I forgot to mention a case where the prosecutor if I remember rightly called me. It was the case in the town of Karlskrona where a young girl was beaten to death by her caretakers. I was really of little use in that case, unlike the psychological expertise but I was very impressed by the speed and competence of the simultaneous interpreters." 20

This case was extensively covered in Swedish mass media in 2014 and 2015 and concerned the death, by brutal beating, of an eight-year-old girl who had arrived from the Gaza Strip a year earlier to live with a maternal uncle and his wife and their two children-a new-born and a child of three. According to newspaper reports, the girl had been sent from Gaza by her parents to overcome trauma from the war. She had quite quickly adjusted to her Swedish school. But there were a number of reports from the social services that her caretakers were not treating her well. They, however, did not intervene, and a year after she had arrived in Sweden, she was dead. The case against the caretakers was never framed in terms of 'religion' or 'culture', and the psychiatric assessment declared them both sane. The uncle was sentenced to life imprisonment and so was the aunt. The district court had given the man a lower sentence, since most of the battering had been committed by the woman, but the court of appeal increased his sentence, claiming he was equally culpable. This case had tragic repercussions. Public and bureaucratic blame for the lack of action was put at the door of the school's head teacher. Although he apparently had done nothing wrong, he was sacked and accused of neglect. He became depressed and later tried to commit suicide. His name and reputation were later rehabilitated.

Another twist to this case was that the Swedish Board of Migration in 2017 granted residence permits in Sweden-due to the distressing circumstances-to the parents of the dead girl and to her three siblings. The mother was not happy with this legal status and appealed to obtain refugee status for herself and her children, in order to ensure that they would never be sent back to Gaza. She was afraid that her husband's relatives regarded her as guilty of the murder of her daughter, since she had placed her with her own relatives in Sweden. According to a news report, she said that if she was forced to return, "they would pressure my husband to divorce me and then they would take the children. The family rules more than the individual, and they think they have to avenge the girl." (Svt Nyheter 2017).

19 In another case in April 2018, the Labor Court decided it was discriminatory to fire a female substitute teacher from a (semiprivate) school because she would not shake hands with male colleagues.

20 For a comparative discussion on translators as experts, see Bouillier (2011). 


\section{Culture, Law and Experts}

It was law professor Claes Lernestedt who alerted me to one of the few cases where an anthropologist had been used as an expert in a criminal case. "There is a case which I frequently use when I teach, where an anthropologist was called in to explain Congolese spirit possession ... "

This case came to trial in a district court in 2000 when three adults-two women and a man-were accused of having killed one child and severely injuring another, both in their care. The accused adults explained that the children had been bewitched (or were witches). The judgement from the district court is more than 40 pages long. It includes a rather detailed description of what happened to the two children during the three days of Christmas, when they were subjected to torture. The three adults had a fairly uniform description of the events, and all three claimed that they had tried to exorcise witchcraft. The statement of the anthropologist, Kajsa Ekholm Friedman, with fieldwork experience from Congo-Kinshasa, is summarized in less than a page. According to the text, she stated that "there are clear differences between the way a Congolese and a Swede understand reality. In Congo evil spirits and witches are part of reality. Personal problems and misfortune are often explained by evil spirits and witches." She also explained that all through the 20th century, there have been movements to cleanse villages from witches. These movements have been more or less violent, and sometimes those accused of being witches have died. "In Congo it is most common that older relatives are perceived to be witches. It is unusual that children are accused, but during the 1990s this had become more frequent in the Kinshasa area." In the assessment of the crime, the court returns to the question of motive and states that this is totally strange "in our culture", but-according to the anthropologist-very real for a great many in Congo-Kinshasa. The court finds "no reason to distrust the accused when they claim that the children were possessed by evil spirits, that they were witches." But when it comes to judging their actions "-in the first case if this constitutes a crime- -this must be done according to the Swedish legal system." The man was sentenced to life imprisonment, the two women were sentenced to four years in prison each, and one was sentenced to deportation without the right to return. Two months later the court of appeal affirmed these judgements. The court thus chose, according to Lernestedt, to ignore the beliefs of the accused. In this case, the 'cultural expert' gave a context to the events, but this context was not taken into account by the court. He calls this a legal silence and comments: "What I find provoking in this case is not necessarily the final outcome but the road to it." (Lernestedt 2014, p. 17$).{ }^{21}$

Apart from this case, there have been, as far as I know, three others involving children being seen as witches or possessed by evil spirits tried in Swedish courts in the 21st century. In one case, a man was sentenced to one year in prison in 2003 for having assaulted and battered three young girls during three years, and also for having taken them to Congo for exorcism. The two other cases were both tried in a district court in southwest Sweden in 2013. These cases also involved immigrants from Congo accused of aggravated assault on preteenage girls. In one of them, two caretakers and two priests were accused and acquitted by the district court but sentenced-except for one of the priests-by the court of appeal.

Josef Nsumbu, a doctor of theology and pastor in Missionskyrkan in the town of Borås, was called as an expert. He explained that in Congo, there are perceptions that children may become possessed by evil spirits and that these spirits can be exorcised in different ways. Such ideas combine old traditions and Christianity, he explained. The district court claimed that the evidence for assault was weak and that exorcism is common in many Christian churches. The court of appeal, however, underlined that although the accused had strong religious motivations, belief cannot legitimate that children are treated in such a way. The priest was sentenced to one year and three months in prison, the man acting as a father to the children was sentenced to two and a half years, and the acting mother to two years.

21 English in the original. 
The last case involved assault committed between 2007 and 2008 but tried in 2013. Here the caretakers were sentenced by the district court. It seems the court had 'learned a lesson' from its previous case a few months earlier, because they sentenced the acting father to one year in prison and the acting mother to eight months. The court declared that the couple had lived in the belief that the girl was a witch. "It is not punishable to believe in witches, and the case is not about what is the right or wrong belief." The court claimed that "there is no god who thinks that children are evil."

Cases of so-called female genital mutilation (FGM) are, like witchcraft, in Sweden mainly associated with immigrants from the African continent. In 1982, Sweden was the first country in the West to pass a law against female genital mutilation. But it was not until the 1990s-with the arrival of many Somali refugees-that the issue came to the fore and became extensively discussed in public (Johnsdotter 2008a, p. 161). Sara Johnsdotter, professor of medical anthropology, has both followed and written extensively about these debates and the legal cases of FGM in Sweden and elsewhere (Johnsdotter 2008b; Mestre i Mestre and Johnsdotter 2019). She was an expert witness in the first ever FGM trial in Sweden. A father, habitually residing in Sweden, was accused of participating in the circumcision/mutilation of his 12-year-old daughter when in Somalia. He was sentenced to two years in prison in a district court. The sentence was reaffirmed by a court of appeal. Johnsdotter argued that the case against the father was deeply flawed, not least because men never take part in FGM. She was also an expert witness in a Danish case where both parents were sentenced although it was not proved that their daughters had, in fact, been circumcised. "In both these cases, I think that the cultural expert did not play any major role. The (political) wish to sentence was too strong, just as the idea of the prevalence of this phenomenon among immigrant communities," Johnsdotter wrote to me in an email.

Johnsdotter's engagement and field of expertise outside asylum cases is rare. Most fellow anthropologists I asked about being experts in cases of litigation told me that they-like religious studies scholars-had not been approached by lawyers except in asylum cases. Sverker Finnström, with expertise on Uganda, has written statements for cases in Sweden, the UK, and the USA. Additionally, I have been contacted by lawyers representing asylum seekers threatened with expulsion. Especially, I have been asked to vouch for the great probability that the expelled would become the victim of family feuding, or 'honor violence', if they were forced to return. In May 2018, for example, I was contacted by a Swedish lawyer looking for information in support of an asylum claim for a Palestinian man. She found that more than a decade earlier, I had been asked by a lawyer in Australia about honor crimes in Jordan. The Swedish lawyer sent me an excerpt from the report by the Australian lawyer, quoting me. I had agreed that in Jordan, men who are accused of having illicit affairs can be subject to threats, adding that to my knowledge, no protection was available from the Jordanian state. However, I also wrote that I had never come across a case in which a man had been killed in an honor crime, since women are generally blamed when a case involves illicit sex. The Swedish lawyer then wanted me to make a statement about the risks for her Palestinian client. He had been accused and tried for sexual harassment (in Jordan) of "a woman from a powerful clan whose husband works in the Royal Guard who might suspect that there was a mutual sexual relation between his wife and the Palestinian man." I was very reluctant to claim anything in this case and was relieved that I could guide her to two young colleagues with up-to-date fieldwork experience in Jordan and Palestine.

\section{Conclusions: The Management of Similarities and Differences}

The cases discussed in this article call for deeper analysis from the perspective of cultural expertise as an umbrella concept that spans across a variety of legal fields and calls for different kinds of experts. How can differences and similarities be discerned in the cases discussed above? And what roles-if any-have the experts played to downplay, produce or manage differences and similarities? The categories chosen-Sami, Roma, and new immigrants-are, as stated, very different. Cases discussed involving Sami demonstrate that the conflicts between them and the state, or private landholders or companies, are, in the contemporary period, seldom framed in terms of 'culture', 
but rather minority rights. ${ }^{22}$ The Roma, as shown, still have to struggle against implicit perceptions on the part of the authorities and society at large that they have a deviant 'culture' which can be linked to particular nondesired behavior. Experts supporting Roma have to argue that to have equal access to justice demands an acknowledgement of difference. The cases discussed involving 'new immigrants' span a wider legal field and cover both civil and criminal law. The case of the bewitched children where the court declared that no god thinks children are evil is interesting. The beliefs of the accused were not doubted, but their 'rationality' was, since all gods are good to children. Apart from the blatantly false statement regarding the fact that gods would be necessarily good towards children, there is an unquestioned assumption that in Sweden, god is kind and benevolent, and hence, also the state is good and benevolent. If we accept cultural expertise in the broad definition proposed by Holden, the question that begs for an answer in the Swedish context is if, and how, the special knowledge brought in court by cultural expertise legitimizes special rights.

In cases of migration and asylum law, a discourse of culture is often tapped into, on the part of clients and their lawyers, even if that concept is not used explicitly. The lawyer who wanted me to argue in favor of her client to avoid expulsion, certainly did. Among mainstream Swedes, the Middle East, and the Muslim world more broadly, is closely associated with patriarchy, tribalism, a lack of gender equality, and with so-called honor crimes. A defense, or an appeal for the right to remain in Sweden, is thus not uncommonly framed as a way to escape from such phenomena. The mother from Gaza also used these perceptions when she wanted a more secure refugee status rather than simply a residence permit, by framing a potential threat from her in-laws in terms of family honor.

In popular and populist discourse-in contrast to debates among legal specialists—honor crimes, and female genital mutilation, for example, are seen as a typical, yet repulsive, part of 'immigrant culture'. One of my informants, Daniel Hedlund, a legal scholar specialized in children and migration law, noted that the concept of 'cultural competence' was, for a while in the 1990s, popular among Swedish bureaucracies and administrative bodies. "After that it was exchanged for 'intercultural competence' and now I think it is mainly about putting the individual before the culture. Difficult issue! I took part in a course on cultural competence at the Board of Migration in perhaps in 2009. It was called The Meetings of Culture. It was mainly about honor violence." Concerning FGM, Sara Johnsdotter underlined that terminology and law has been politicized. "In a vain effort to bring a case to prosecution, legal borders are crossed in an unacceptable way when it comes to the rights of citizens."

Crime, punishment and laws have increasingly become topics through which an 'us' is produced and mobilized against an imagined 'other'. In the words of legal scholar Mosa Sayed in an email: "In today's legal and political situation it would be suicide to call on 'culture' in trials." 'Culture' has increasingly been used, both implicitly and explicitly, in public debates, not only by demagogues on the far right and racists, but also by mainstream opinion-makers. Generally speaking, anthropologists and other 'cultural experts' have been against tapping into it, or becoming part of that discourse. ${ }^{23}$ Such an ambivalence is expressed by many other 'cultural experts' (e.g., Good 2008; Bouillier 2011; Holden 2011, 2019a), indicating a reluctance to reduce complexity for the sake of clarity. However, the concept of cultural expertise does not plead for the use of culture in trials but wants to account for the use of socio-anthropological knowledge as a support to the administration of justice (Holden 2019b). The cases mentioned by this paper in fact confirm the relative frequency of the use of cultural expertise even in Sweden, in spite of the novelty of its conceptualization.

In conclusion, the widespread reluctance among anthropologists to use the term 'culture' in a way that counteracts populism discloses a dangerous ambivalence that may also result in the incapacity or

22 For interesting discussion on a 'rights discourse' versus a 'culture discourse' see (Good 2008).

23 A twist to the expert role of Roma witness ethnologist Arnstberg, and the anthropologist Kajsa Ekholm Friedman, is that in the last decade, both have become closely associated with right-wing ideas about the need to protect Sweden from multiculturalism and cultural diversity. 
unwillingness to actually take a stand. Swedish cultural experts have a long history of being entwined with the state. This is changing, but more debate is needed to develop the roles of such experts (see Mestre i Mestre and Johnsdotter 2019, p. 106).

Perhaps cultural experts, according to the broad definition suggested by Holden, could look more closely at the nuanced argumentation of legal scholars to find support for managing difference within a legal system where equality and the protection of the weaker party has to be maintained. Aylet Shachar's (2014) discussion on culture as a shield or a sword in civil law opens up for a way to be sensitive to context, without denying the conflicts inherent in cultural claims. Meanwhile, Lernestedt $(2010,2014)$ encourages scrutiny of the content of the yardsticks we use in the legal system. The Swedish state, which is quite blind to its multicultural history, should not be blind to justice. In Sweden, an alliance-or even a simple conversation-between cultural experts concerned with litigation, and legal scholars interested in the expertise of such persons, could be a first step towards fruitful interdisciplinary research and practical action.

Funding: This essay was first presented at the EURO-EXPERT conference held in Oxford on the 3rd and 4th July 2018 and has benefitted from funds from EURO-EXPERT, ERC funded project 681814 led by Livia Holden, the Principal Investigator.

Acknowledgments: I would like to thank all the colleagues and experts named in this text who helped me with material. Without their interest and support, this article could not have been written.

Conflicts of Interest: The author declares no conflict of interest.

\section{References}

Beach, Hugh. 1981. Reindeer-Herd Management in Transition. The Case of Tuorpon Saameby in Northern Sweden. Uppsala: Uppsala Studies in Cultural Anthropology.

Bouillier, Véronique. 2011. French law courts and South Asian litigants. In Cultural Expertise and Litigation. Edited by Livia Holden. Milton Park: Routledge, pp. 53-70.

Dagens Nyheter. 2014. Mörkertalet är jättestort. Dagens Nyheter. March 26. Available online: https://www.dn.se/ nyheter/sverige/morkertalet-ar-jattestort/ (accessed on 15 September 2019).

Dagens Nyheter. 2015. DN Debatt, 2015. Rasbiologiskt språkbruk i statens rättsprocess mot sameby. Dagens Nyheter. June 11. Available online: https://www.dn.se/debatt/rasbiologiskt-sprakbruk-i-statens-rattsprocess-motsameby/ (accessed on 15 September 2019).

Ds. 2014. Den mörka och okända historien. Vitbok om övergrepp och kränkningar av romer under 1900-talet. Arbetsmarknadsdepartementet: p. 8. Available online: https://www.regeringen.se/rattsliga-dokument/ departementsserien-och-promemorior/2014/03/ds-20148/ (accessed on 15 September 2019).

Good, Anthony. 2006. Anthropology and Expertise in Asylum Courts. Abingdon: Routledge.

Good, Anthony. 2008. Cultural evidence in courts of law. Journal of the Royal Anthropological Institute 14: S47-S60. [CrossRef]

Government Offices of Sweden. 2007. National Minorities and Minority Languages. Available online: https://www.government.se/49b72e/contentassets/bb53f1cff8504c5db61fb96168e728be/national-minoritiesand-minority-languages (accessed on 21 March 2019).

Holden, Livia, ed. 2011. Introduction. In Cultural Expertise and Litigation. Milton Park: Routledge, pp. 1-10.

Holden, Livia, ed. 2019a. Cultural Expertise and Socio-Legal Studies. Studies in Law, Politics, and Society. Bingley: Emerald.

Holden, Livia, ed. 2019b. Beyond Anthropological Expert Witnessing: Toward an Integrated Definition of Cultural Expertise. In Cultural Expertise and Socio-Legal Studies. Studies in Law, Politics, and Society. Bingley: Emerald, pp. 181-204.

Jahreskog, Birgitta. 1982. The Sami National Minority in Sweden. Stockholm: Almqvist \& Wiksell International for The Legal Rights Foundation.

Johnsdotter, Sara. 2008a. Ali och den svenska rättvisan: Det första könsstympningsmålet. Malmö: Egalité.

Johnsdotter, Sara. 2008b. Popular notions of FGC in Sweden: The case of Ali Elm. Finnish Journal of Ethnicity and Migration 3: 74-82.

Lernestedt, Claes. 2010. Dit och tillbaka igen. Om individ och struktur i straffrätten. Uppsala: Iustus förlag. 
Lernestedt, Claes. 2014. Criminal law and 'culture'. In Criminal Law and Cultural Diversity. Edited by Will Kymlicka, Claes Lernestedt and Matt Matravers. Oxford: Oxford University Press, pp. 15-46.

Lundmark, Lennart. 2006. Samernas Skatteland I Norr- och Västerbotten under 300 År. Stockholm: Institutet för Rättshistorisk Forskning.

Mestre i Mestre, Ruth, M., and Sara Johnsdotter. 2019. Court cases, cultural expertise, and 'female genital mutilation' in Europe. Studies in Law, Politics, and Society 78: 95-113.

Mörkenstam, Ulf. 1999. Om "Lapparnes privilegier": Föreställningar om samiskhet i svensk samepolitik 1883-1997. Stockholm: Stockholms Universitet.

Mörkenstam, Ulf. 2002. Bilden av den andra i svensk samepolitik. In Svenska Värderingar? Edited by Peter Hallberg and Claes Lernestedt. Stockholm: Carlsson Bokförlag, pp. 49-71.

Nafstad, Ida. 2016. Gypsy law-The non-state normative orders of Roma: Scholarly debates and the Scandinavian knowledge chasm. The Journal of Legal Pluralism and Unofficial Law 48: 92-109. [CrossRef]

Olgaç Rodell, Christina. 2006. Den romska minoriteten i majoritetssamhällets skola: från hot till möjlighet. Stockholm: HLS förlag.

Renteln, Alison. 2004. The Cultural Defence. Oxford: Oxford University Press.

Runcis, Maija. 1998. Steriliseringar i folkhemmet. Stockholm: Ordfront.

SCB. 2018. Utländska medborgare i Sverige. Available online: https://www.scb.se/hitta-statistik/sverige-i-siffror/ manniskorna-i-sverige/utlandska-medborgare-i-sverige/ (accessed on 21 March 2019).

Shachar, Aylet. 2014. Family matters: Is there room for 'culture' in the clurtroom? In Criminal Law and Cultural Diversity. Edited by Will Kymlicka, Claes Lernestedt and Matt Matravers. Oxford: Oxford University Press, pp. 119-52.

SOU. 1996. Sverige, Framtiden och Mångfalden. Slutbetänkande från Invandrarpolitiska Kommittén. Stockholm: Fritze, p. 55 .

Svanberg, Ingvar, and Mattias Tydén. 2005. Tusen år av invandring. En svensk kulturhistoria, 3rd ed. Stockholm: Dialogos.

Svt Nyheter. 2017. Yaras familj har fått permanent uppehållstillstånd. Svt Nyheter, February 26.

(C) 2019 by the author. Licensee MDPI, Basel, Switzerland. This article is an open access article distributed under the terms and conditions of the Creative Commons Attribution (CC BY) license (http://creativecommons.org/licenses/by/4.0/). 